\title{
The Curiosity of Education Faculty Students in Learning
}

\author{
Hartini, Sunaryo Kartadinata, Syamsu Yusuf LN, M. Solehuddin, Edi Wahyudi M
}

\begin{abstract}
In this study we described the curiosity of education faculty students in learning based on aspects of interest, noveltyseeking, the openness of experience and exploration. We used cross-sectional survey with a quantitative approach to collect data and to measure curiosity in learning we used questionnaire. The participants were 286 spread across 9 study programs in the faculty of education. The results showed that students sometimes have a curiosity in learning. This condition explained the curiosity of students in learning tends to be in the medium category and tends to be low because the number of students who are rare and never curiosity in learning more than students who often and always curiosity in learning.
\end{abstract}

Keywords: Curiosity, interest, novelty-seeking, the openness of experience and exploration

\section{INTRODUCTION}

Development of curiosity in learning can be used as a component in preparing for the 21st century's superior generation, because it is an important metacognitive skill in the context of education [1]. Individuals who have a high level of curiosity will be able to remember what has been learned longer than individuals who are less curious about the variety of information provided [2] [3]. Besides curiosity plays an important role in maintaining cognitive functions, mental health, and physical [4], and academic achievement [5], so that curiosity is increasingly felt as a virtue that needs to be developed in the learning process in education.

Empirical data shows that there are still educators who are not skilled in giving questions that can lead to curiosity in learning [6]. This condition illustrates the need to improve the quality of educators and education personnel in carrying out their roles at the educational level. Improvements have been carried out using routine supervision strategies from the principal, through training, seminars, technical guidance, and workshops, as well as evaluating the performance of educators and education staff [7]. However, this strategy is the role of external factors, so that the maximum results it is necessary to increase from the internal factors that began to be developed by prospective students. the results of the study found that: teacher

Revised Manuscript Received on December 30, 2019.

* Correspondence Author

Hartini*, State Institute of Islamic Studies (IAIN) Curup, Curup, Indonesia. Email: Hartini@iaincurup.ac.id

Sunaryo Kartadinata, Universitas Penddikan Indonesia (UPI) Bandung, Indonesia. Email: Kartadinata@upi.edu

Syamsu Yusuf LN, Universitas Penddikan Indonesia (UPI) Bandung, Indonesia...Email: Yusuf@upi.edu

M. Solehuddin. Universitas Penddikan Indonesia (UPI) Bandung, Indonesia. Email: Solehuddin@upi.edu

Edi Wahyudi M, State Institute of Islamic Studies (IAIN) Curup, Curup, Indonesia. Email: ediwahyudi@iaincurup.ac.id

(C) The Authors. Published by Blue Eyes Intelligence Engineering and Sciences Publication (BEIESP). This is an open access article under the CC BY-NC-ND license (http://creativecommons.org/licenses/by-nc-nd/4.0/) actualization can be increased through supervision and achievement motivation of school principals [8], work motivation of school principals has a positive and significant effect on teacher performance [9] but academic qualifications, work experience, work motivation and task awareness affect the performance of the school principal [10] [11].

This confirms that efforts to improve the quality of educators and education personnel through the performance of school principals can be achieved depending on work experience, academic qualifications, performance motivation and task awareness. Even the Principal should follow and apply the development of science and technology [12].

This condition illustrates that the role of external factors is more dominant in realizing the quality of educators and education personnel through competent principals. This needs to be observed and balanced so that the role of internal factors of educators should be more prominent. Through the development of curiosity in learning of students as prospective educators it is predicted to be able to encourage the formation of competencies and strengthen internal factors in achieving educational goals when carrying out the role as educators later. The development of curiosity in learning will encourage learning that is expected to be a learning model that is able to create a learning process that is fun, free, and not boring [13]. This learning is expected to implement the character of education to develop the characteristics of students [14], on the other hand whether the school can provide space to foster creativity of students [15]. The answer certainly can be realized if the school is filled with competent educators who are able to develop the learner's curiosity in learning. A learning fun process can foster student creativity and is a challenge for universities to make it happen. Preparing competent teacher candidates to be able to develop students' curiosity in learning will hone their competencies so they are able to apply them to students after they become teachers later. Curiosity is the quality of a thought related to exploration, investigation and learning, as evidenced by observing [16]. Curiosity is a key element in independent learning, which is related to the desire to achieve an optimal level of arousal [17]. Curiosity is characterized by an interest in an object that is found, looking for novelty in that object, and opening the desire to gain experience through deep exploration in order to solve problems [18], as well as the learning process undertaken to gain knowledge and skills are very closely related to all aspects of human development [19], so that curiosity becomes something that is important for all humans to meet the needs and challenges of life. Basically the development of curiosity has been done by many previous researchers including using inquiry-based learning approaches such as problem-based learning [20], building four models of logical associations between inquiry questions as a framework for open inquiry plans on subjects [21], the ability to discuss things with others will strengthen the curiosity of individuals 


\section{The Curiosity of Education Faculty Students in Learning}

[22], openness in thinking students will foster curiosity [23] and the state of flow in conducting activities can lead to curiosity. [24] [25]. Even curiosity research and development in Indonesia in the last ten years have also been carried out starting at the elementary, junior high, high school and university levels so that various information regarding strengths, weaknesses and factors and impacts have been carried out. gained in developing to curiosity in learning that is the development of student curiosity in effective learning to build self-confidence and interest [26] and students experience an increase in learning through the provision of teaching using story books [27]. The application of the model Project Based Learning with scaffolding has been proven to improve the curiosity character and mathematical communication skills of students in learning [28], and learning using the media puzzle also increases students' curiosity in learning history [29], but the approach problem posing and problem solving in terms of achievement and curiosity are not effective in improving mathematical learning [30] and there is a weak relationship between reading pre-class activities with and students' curiosity about science [31]. While Zetriuslita, et al. [32] [33] the application of problem-based learning cognitive conflict strategies is more influential in developing critical thinking, especially communication skills and curiosity using the Problem Based Learning Model and Cognitive Conflict Strategy (PBLCCS) and Explicit Direct Instruction (EDI).

When examined in terms of gender, class levels and majors explain the curiosity in learning there is no difference [34] [35]. While research in terms of the 2013 curriculum develops the character of curiosity and concern social curriculum in 2013 where to form the character of curiosity and social awareness, educational instruments such as competent teachers, adequate learning resources, learning actions in the form of approaches, models, methods, and appropriate learning strategies [36]. this underscores the importance of developing the curiosity of students as prospective teachers to meet the educational instruments so that they have the competencies required in order to develop the curiosity of students in higher learning should or half grade levels should be increased curiosity in learning. Prepare instrument of education, it becomes important point that must be done by universities as an effort to meet the needs so that the development of student curiosity in learning at every level of education can be implemented. Prospective teachers who are competent become point the main that needs to be prepared in order to be able to develop the characteristics of students' curiosity in learning. Prospective teachers who have reliable competence will be able to choose the right learning resources, approaches, models, methods, or learning strategies that have a positive effect on the mastery of subject matter and academic achievement of students. Therefore, the development of the curiosity of prospective teachers who are studying in tertiary education institutions (PT) is very necessary as an effort to improve the quality of prospective teachers so that they have reliable and professional competence. But before the development of student curiosity is carried out it is necessary to analyze the achievements of the students' curiosity in learning so that development can be carried out in accordance with problems and needs.

\section{THEORY REVIEW}

Universal desires for intellectual activity or the need for cognition (interest) in order to obtain happiness based on values, acquire new skills, collect, and analyze information are the essence of curiosity [37]. Interest in the objects found, looking for novelty in these objects, and opening the desire to gain experience through deep exploration in order to solve problems is a sign of curiosity [18].

The desire to seek the sensation of experience (openness of experience), seek adventure, be prone to boredom, and the willingness to take risks in getting new things or novelty seeking is also part of curiosity [38], so curiosity focuses on orientation towards investigating certain events or objects [39], and motivating individuals to search for new experiences (openness of experience) and strengthen exploration [40].

Curiosity becomes the drive in seeking newness of information (novelty seeking) [17] is shown when an individual: a) reacts positively to something new, strange, out of tune, or mysterious elements in their environment by moving toward exploring or by manipulating, b) showing the need or desire to know more about themselves. and / or the environment c) scan the surroundings for new experiences. d) persist in examining and exploring stimuli to find out more about them [41]. Besides, curiosity is used as an aspect of intrinsic motivation that has great potential to enhance student learning [20].

Various notions of curiosity in above, it can be interpreted that curiosity is a curiosity of individuals in understanding the object, gathering and analyzing information so as to find the novelty of information and new skills so that they can experience and thrill of adventure in problems encountered. The curiosity in learning is a curious individual to know and understand knowledge in learning, curiosity in learning that is marked by interest, looking for newness, doing deep exploration, and exploration of the knowledge learned. Curiosity in learning can develop creativity, self-potential i, pleasure, satisfaction, enthusiasm, and eliminate boredom by displaying the power of cognitive enthusiasm in answering curiosity about the science being studied. When studied conceptually curiosity in learning has several components namely interest, novelty-seeking, openness of experience and exploration [16][18][38] [39] [40] [17]. A series of learning processes through exploration will form if students have an interest or interest in the knowledge learned. Interest will be the main trigger for the formation of a deep curiosity towards science that is served in the learning process. Interest can be expressed through analyzing the interests, attention, curiosity, and challenges [18] perceived by students towards the subject matter faced. Furthermore, curiosity in learning involves a process of active recognition, the pursuit, and regulation of experience in responding to opportunities and challenging in seeking novelty (Novelty-seeking). Basically, looking for newness is described as an emotional-motivational state of students in facilitating and stimulating the search for new things, complexity, uncertainty, and conflict in the learning process that is formed through strong associations between courage and social skills so that it will suppress boredom and anxiety in study. 
Novelty-seeking can be revealed through finding new things, solving problems or uncertainties, seeking enjoyment and pleasure in learning, feeling the sensation of adventure, conflict and complexity of various problems and knowledge learned [18] [38]. Looking for novelty in the learning process and solving problems due to uncertainty is a form of learner's curiosity to understand lecture material in depth. Fulfilling curiosity in learning not only through attractiveness and novelty, but also through the development of openness of experience. Curiosity in learning becomes a fundamental motivational component of all aspects of openness that involves active recognition of the pursuit and regulation of experience in responding to challenging opportunities so that creativity emerges and meets the desired knowledge needs. Opening experience (openness of experience) in the learning process becomes something interesting for students because it can increase learning stimuli at optimal levels that can shape openness to new values and ideas that are future-oriented [18]. This implies that the experience-based learning process can stimulate students to find new values.

Exploration is also part of fulfilling students' curiosity in the learning process. Exploration in the learning process occurs through investigation and depth exploration [39] [18]. The investigation will produce detailed data in accordance with the needs so that the investigation can be used as a medium for educators to arouse the desire of students to know more about the lecture material provided. In-depth exploration process students need to do in order to gain complete knowledge and understanding in the learning process. Exploration of lecture material is a means to develop student competencies in the process of analyzing lecture material.

\section{RESEARCH METHODS}

This study used a cross-sectional survey with a quantitative approach. Subjects Research numbered 286 students who were undergoing education in semester III, V, VII. Students are taken by random sampling in 9 study programs at the Faculty of Education. The instrument used in the form of a questionnaire that will reveal the curiosity of students in learning that includes interest, novelty seeking, openness of experience and exploration in learning. The scoring model uses scale Likers consisting of five categories, namely: 1) Always, 2) often, 3) sometimes, 4) rarely, and 5) never. The number of questionnaire was 48 items with a reliability level of 0.886 . Data analysis using SPSS so that the results of the study will obtain descriptive statistical data and achievements of student curiosity in learning.

\section{RESULTS AND DISCUSSION}

The results of data collection on 286 students of the Faculty of Education who were studying in semesters III, V and VII in Nine Studies namely: namely Islamic Education Counseling Guidance, Islamic Education Management, Islamic Religious Education, Tadris English, Indonesian, Madrasa Teacher Education Ibthidaiyah, Early Childhood Islamic Education, Mathematics, Arabic Language Education are broken down in the following table 1:
Table 1.

Descriptive Statistics of Student Curiosity in Learning

\begin{tabular}{cccccccc}
\hline $\begin{array}{c}\text { Variable/ } \\
\text { Sub } \\
\text { Variable }\end{array}$ & N & Min & Max & Sum & Mean & $\begin{array}{c}\text { Std. } \\
\text { Devi } \\
\text { ation }\end{array}$ & $\begin{array}{c}\text { Skor } \\
\text { Ideal }\end{array}$ \\
\hline Curiosity & 286 & 119 & 222 & 45678 & 159.71 & $\begin{array}{c}19.3 \\
1\end{array}$ & 240 \\
\hline Interest & 286 & 26 & 54 & 11238 & 39.29 & 5.22 & 60 \\
$\begin{array}{c}\text { Novelty } \\
\text { Seeking }\end{array}$ & 286 & 33 & 74 & 14338 & 50.13 & 7.17 & 75 \\
$\begin{array}{c}\text { Openness } \\
\text { Of }\end{array}$ & 286 & 36 & 70 & 14432 & 50.46 & 7.13 & 75 \\
$\begin{array}{c}\text { Experience } \\
\text { Exploration }\end{array}$ & 286 & 10 & 29 & 5670 & 19.83 & 3.27 & 30 \\
\hline
\end{tabular}

The results of descriptive statistics showed that the curiosity of students in learning obtained score of mean 156, 18 from the expected maximum score of 240 with a standard deviation score of 19.31. When examined from the aspect of interest on the lecture material being studied is obtained score of mean 39, 25 of the expectations of a maximum score of 60, seek novelty in learning acquisition score mean of 50,13 out of a score of 75 is expected, openness to experience learning the acquisition of score mean 50.46 from the expectation of a maximum score of 75 and deep exploration activities in the learning activities of the acquisition of score of mean 19.839 from the expected 30 score. Obtaining descriptive statistics has a meaning based on the classification of curiosity in learning as in table. 2 below:

Table 2.

Classification of Student Curiosity in Learning

\begin{tabular}{cccc}
\hline Score & Category & $\mathbf{F}$ & $\mathbf{\%}$ \\
\hline $\mathbf{X}>\mathbf{1 8 9}$ & Very High & 17 & 5.9 \\
$\mathbf{1 7 0} \leq \mathbf{X} \leq \mathbf{1 8 8}$ & High & 76 & 26.6 \\
$\mathbf{1 5 1} \leq \mathbf{X} \leq \mathbf{1 6 9}$ & Moderate & 92 & 32.2 \\
$\mathbf{1 3 1} \leq \mathbf{X} \leq \mathbf{1 5 0}$ & Low & 86 & 30.1 \\
$\mathbf{X}<\mathbf{1 3 0}$ & Very Low & 15 & 5.2 \\
\hline
\end{tabular}

The results of the analysis based on classification show the student's curiosity in learning as a whole the highest score in the medium category, there are 92 students or 32\% who sometimes have a curiosity in learning, while 101 students or $35.3 \%$ are rare and there are those who never want to learn in learning and there are 93 students or $32.5 \%$ often and always want to learn. This condition explains the curiosity of students in learning in the medium category and tends to decrease because the number of students who rarely and never want to learn more than students who often and always want to learn. Curiosity in learning is also analyzed based on aspects of interest, novelty seeking, openness of experience and exploration. The classifications are broken down in the following table 3 : 


\section{The Curiosity of Education Faculty Students in Learning}

Table 3.

Classification Curiosity Students in Learning based on aspects of interest, novelty seeking, openness of experience and exploration

\begin{tabular}{|c|c|c|c|c|}
\hline $\begin{array}{r}\text { Score } \\
\text { Category }\end{array}$ & Interest & $\begin{array}{l}\text { Novelty } \\
\text { Seeking }\end{array}$ & $\begin{array}{c}\text { Openness } \\
\text { of } \\
\text { Experience }\end{array}$ & Exploration \\
\hline $\begin{array}{l}\text { Very } \\
\text { High }\end{array}$ & $X>48$ & $X>61$ & $X>62$ & $X>25$ \\
\hline High & $\begin{array}{c}42<X< \\
47\end{array}$ & $53<X<60$ & $54<X<61$ & $21<X<24$ \\
\hline Moderate & $\begin{array}{c}37<\mathrm{X}< \\
41\end{array}$ & $46 x<52$ & $46 \mathrm{X}<53$ & $18 X<20$ \\
\hline Low & $\begin{array}{c}32<\mathrm{X}< \\
36\end{array}$ & $40<X<45$ & $40<X<45$ & $15<X<17$ \\
\hline $\begin{array}{l}\text { Very } \\
\text { Low }\end{array}$ & $<31$ & $<39$ & $<39$ & $<14$ \\
\hline
\end{tabular}

Based on the Classification of Student Curiosity in Learning based on aspects of interest, novelty seeking, openness of experience and exploration, the student's curiosity in learning in each aspect is as described in table 4 below:

Table 4.

Student Curiosity in Learning Based on Aspects of Interest, Novelty Seeking, Openness of Experience and Exploration

\begin{tabular}{lcccccccc}
\hline Aspects & Interest & \multicolumn{2}{c}{$\begin{array}{c}\text { Novelty } \\
\text { Seeking }\end{array}$} & \multicolumn{2}{c}{$\begin{array}{c}\text { Openness } \\
\text { of } \\
\text { Experience }\end{array}$} & Exploration \\
\hline & & & & & & & \\
\hline & & $\%$ & $\mathrm{~N}$ & $\%$ & $\mathrm{~N}$ & $\%$ & $\mathrm{~N}$ & $\%$ \\
\hline $\begin{array}{l}\text { Very } \\
\text { High }\end{array}$ & 2 & 0.7 & 12 & 4.2 & 14 & 4.9 & 14 & 4.9 \\
\hline High & 90 & 31.5 & 92 & 32.17 & 71 & 24.8 & 71 & 24.8 \\
\hline Moderate & 118 & 41.3 & 76 & 26.57 & 99 & 34.6 & 99 & 34.6 \\
\hline Low & 57 & 19.9 & 83 & 29.02 & 77 & 26.9 & 77 & 26.9 \\
\hline $\begin{array}{l}\text { Very } \\
\text { Low }\end{array}$ & 19 & 6.6 & 23 & 8.04 & 25 & 8.7 & 25 & 8.7 \\
\hline Total & 286 & 100 & 286 & 100 & 286 & 100 & 286 & 100 \\
\hline
\end{tabular}

The data in table 4 explains that in the aspect of interest that is the student's interest in lecturing material the highest score in the medium category is 118 students or $41.3 \%$ sometimes interested in lecture material and sometimes there are not even 76 students or $26,5 \%$ at low and very low classifications marked by students were rarely even not interested in lecture material and 92 students or $32.8 \%$ curiosity at high and very high classifications were marked by students often and always interested in lecture material.

Student curiosity in the aspect of novelty seeking that is looking for new knowledge and responding to challenging opportunities in the learning process explained that the highest score was $32.17 \%$ or 92 students in the high classification but $37,06 \%$ or 106 students were in the low and very low classification. And $36.37 \%$ or 104 students in the category of moderate.

The aspect openness of experience of $34.6 \%$ openness of insight and original ideas in the learning process explained that the highest score was\% or 99 students in the medium classification, $35.6 \%$ or 102 students in the classification low and very low, and 85 students or $29.7 \%$ in the high and very high classification.
Student curiosity in the aspect of exploration of the highest score of $34.6 \%$ or 99 students in the medium classification, $29.7 \%$ or 85 students in the high and very high classification and $35.6 \%$ or 102 students in the low and very low classification.

Achievement of student curiosity in learning explains the problems and needs that need to be considered and resolved by counselors and lecturers so that students' curiosity in learning can be increased. When analyzed based on the item items of the aspect of interest, it describes a student's cognitive interest, attention, curiosity and a sense of challenge to the subject matter but the attitude and learning behavior do not reflect the knowledge they have. This condition needs to be considered because competence is generally defined as integrated pieces of knowledge, skills and attitudes [42], but the condition of competency possessed by students has not displayed a complete integration. So that the impact on the achievement of requirements as a function of activity adequately [43] [44]. This condition raises the question of what is integrated between knowledge, skills, and attitudes actually mean and how it is achieved? This question is answered when a student is confronted with well-defined professional assignments and he has the knowledge, skills and attitudes needed for adequate task performance, these students tend to show low-road integration so task performance may be fast and smooth, knowledge, skills and attitudes automatically connected in performance, and students do not have to think consciously about what they are doing [45].

In the aspect of novelty seeking students have described the desire to seek newness of knowledge and respond to challenging opportunities in the learning process through problem solving, being able accept changes and criticism and understand the integrity of the material in conducting the learning process. But the attitude and skills / practice have not been carried out in accordance with expectations as students tend to rarely develop lecture topics by using the latest references, studying lecture material deeper, linking subject matter with various problems in the field, conducting an assessment of knowledge has been learned as a barometer of the advanced learning process, exploring various information in print and electronic media to understand the lecture material in full, thinking visiting schools in remote villages will get more accurate information about the phenomena in learning, making summaries on lessons that have complexity in order to find the truth of the material being studied, thought that understanding conflict and complexity of lecture material can form analytical skills in the learning process and tend to rarely make a summary of various subject matter in full after completing the learning process an.

The condition of the aspect of the achievement of novelty seeking is similar to the aspect of interest, which is knowledge already possessed, but the attitude and skills have not occurred as it should. When examined from a psychological perspective, the type of knowledge includes declarative knowledge, procedural knowledge and strategic or metacognitive knowledge. Declarative knowledge is factual information that someone knows and can report [46]. Procedural knowledge is the connection or use of pieces of declarative knowledge, and generally refers to knowledge that cannot be communicated.




Strategic or metacognitive knowledge, relating to knowledge of the task, context, problem solving process and self [47].

When analyzed further the achievements of student curiosity on aspects of novelty seeking, including declarative knowledge. Some researchers distinguish declarative knowledge as knowing it and knowing how [48], where knowing it refers to knowledge of facts, concepts and definitions, and knowing how to refer to knowing how to do something without actually acting. The conditions of knowledge know that and know how this is happening to students so that the achievement of declarative knowledge is labeled according to the achievements they have. Therefore, the declarative knowledge that students already have can be internalized deeply so that connections with skills in the form of real learning behavior occur. The connection between knowledge and skills will occur through reflection in which the student must think consciously about what he is doing [45]. Awareness of students is a form of attitude that will arise if they know and understand the goals and achievements that must be taken in following the learning process so that awareness needs to be developed within the student body.

In the aspect of openness of experience, students have thought that learning experiences carried out will produce new values in the learning process, feel the need to find new values every time doing deep learning activities, study the subject matter seriously in order to be able to act professionally when dealing with participants later students, think the lecture material discussed is a basic capital in undergoing a career, feel the need to find a learning method that is fun in order to enjoy the learning process faced by students, discussions with friends can complement and enrich the subject matter that has been discussed.

But student learning behavior tends to rarely find out scientifically if there is a shift and change in the value of a knowledge being studied, repeating lecture material to recall when facing exams, interpreting lecture assignments as a vehicle for developing learning experiences, addressing confusion when learning as art that needs to be enjoyed, reading books about topics being studied will stimulate deeper thinking, completing lecture assignments that can develop imagination in learning, making concept maps (mind mapping) of lecture material by imagining various questions that might arise during an exam, completing notes after completion of the lecture can strengthen understanding of the material that has been discussed ,, and students tend to rarely make conclusions on the lecture material that has been discussed.

Conditions illustrate that the integration of knowledge, attitudes and skills has not occurred as it should so that the mastery of competencies is hampered development. Competency development emphasizes that students must not only acquire but also integrate knowledge, skills and attitudes to achieve competence [43]. Even affirming integrated knowledge, skills and attitudes can be used to achieve success in carrying out professional tasks [45]. This should be a reflection and emphasis for students that the integration of knowledge, skills and attitudes is a means that can bring them success and success in applying knowledge and profiles of graduates in the field later.

Achievement of student curiosity on aspects of exploration in the process of deep exploration relating to analyzing in-depth subject matter that is not yet understood, using various methods / methods to answer lecture material that is difficult to understand and fully involved in learning will facilitate in-depth exploration is still rarely done. While looking for experiences in the learning process students feel learning experiences can be obtained through the desire to learn new things in the lecture material, but students tend to rarely look for various learning resources to find new ideas while learning and think to practice the material that has been learned will strengthen the experience and knowledge while studying.

Exploration is part of fulfilling curiosity student in the learning process. Exploration in the learning process occurs through in-depth investigation and exploration [39] [18]. The development of exploration in students should be directed to clear achievements in order to make it easier for them to explore more deeply and effectively in terms of time. Exploration is directed and some is not directed. Exploration that is directed produces faster learning and always manages to find it optimally, whereas exploration is not directed largely to fail in identifying the optimal solution [49]. The use of various motives is also needed in conducting exploration considering that each method has weaknesses, therefore many methods will help to obtain more and more solid information so students can explore and find novelty in each material discussed

\section{CONCLUSION}

Student curiosity in learning to achieve declarative knowledge, that is, knowing information refers to knowledge of facts, concepts and definitions, knowing how to do things without actually acting. The integration of knowledge, attitudes and skills in developing curiosity in learning has not been formed properly so that it will affect the competencies possessed. Based on the results of this research it is necessary to efforts by educators to develop knowledge that can be owned curiosity shape the attitudes and skills learning through reflection and the provision of a variety of experience and practice in the form of tutoring and learning.

\section{ACKNOWLEDGMENT}

We would like to express our special thanks and gratitude to our rector IAIN Curup (Dr. Rahmad Hidayat, M.Ag., M.Pd), Director of the Postgraduate University of Indonesian Education (Prof. Dr. H. Yaya Sukjaya Kusumah, M.Sc) and Head of the Department of Guidance and Counseling study program at the Indonesian Education University (Dr. Nandang Budiman, M.Sc) along with his staff who gave us support to carry out this extraordinary project.

\section{REFERENCES}

1. T. Sinha, Z. Bai, and J. Cassell, "A New Theoretical Framework for Curiosity for Learning in Social Contexts," no. June, 2017.

2. J. D. Cunningham, "On Curiosity and Science Education John," Sch. Sci. Math., pp. 805-816, 1966.

3. G. Galli et al., "Learning facts during aging: the benefits of curiosity," Exp. Aging Res., vol. 00, no. 00, pp. 1-18, 2018.

4. M. Sakaki, "Neuroscience and Biobehavioral Reviews Curiosity in old age: A possible key to achieving adaptive aging," Neurosci. Biobehav. Rev., vol. 88, no. January, pp. 106-116, 2018.
Published By:

Blue Eyes Intelligence Engineering \& Sciences Publication 


\section{The Curiosity of Education Faculty Students in Learning}

5. E. Greenberger, "The Development of New Measures of Curiosity for Children. Report No. 56.," 1969.

6. M. Kecskemeti, "The Stance of Curiosity in the Classroom Is There a Place for Counselling Skills in Teachers ' Work?," J. Couns. (SPECIAL Sect. Couns. Sch., vol. 33, no. 1, pp. 36-53, 2013.

7. H. Irmayani, D. Wardiah, and M. Kristiawan, "The Strategy Of SD Pusri In Improving Educational Quality,” no. July, 2018.

8. D. Wardiah and M. Kristiawan, "The Influence Of Headmaster ' Supervision And Achievement Motivation On Effective Teachers,' no. July, 2018.

9. S. Andriani, N. Kesumawati, and M. Kristiawan, "The Influence Of The Transformational Leadership And Work Motivation On Teachers Performance," vol. 7, no. 7, pp. 19-29, 2018.

10. Salwa, M. Kristiawan, and B. Lian, "The Effect Of Academic Qualification , Work Experience And Work Motivation Towards Primary School Principal Performance,” Int. J. Sci. Technol. Res., vol. 8, 2019.

11. U. Khasanah, M. Kristiawan, and Tobari, "The Implementation Of Principals ' Academic Supervision In Improving Teacher s Professionalism In The State Primary Schools," Int. J. Sci. Technol. Res., no. August, 2019.

12. D. Apriana, M. Kristiawan, and D. Wardiah, "Headmaster ' s Competency In Preparing Vocational School Students For Entrepreneurship,” Int. J. Sci. Technol. Res. Vol. 8, Issue 08, August 2019, no. August, 2019.

13. Novelti, M. Kristiawan, and Erpidawati, "Development of the Descriptive Writing Learning Model using the Audio Visual Media," Int. J. Recent Technol. Eng. ISSN 2277-3878, Vol. Issue-3, Sept. 2019 Dev., no. September, 2019.

14. H. Fitria, M. Kristiawan, and A. Rasyid, "The Educational Character on Instruction," Opción, Año 35, Espec. No.21 964-979 ISSN 10121587/ISSNe 2477-9385, no. April, 2019.

15. B. Lian, M. Kristiawan, and R. Fitriya, "Giving Creativity Room To Students Through The Friendly School's Program," Int. J. Sci. Technol. Res. Vol. 7, ISSUE 7, JULY 2018, no. July, 2018.

16. B. Y. D. E. Berlyne, "An Experimental Study Of Human Curiosity," Br. J. Psychol. Gen. Sect. 45(3), 180-191., no. D, pp. 256-265, 1954.

17. G. Loewenstein, "The Psychology of Curiosity: A Review and Reinterpretation," vol. 116, no. 1, 1994

18. C. Peterson and M. E. P. Seligman, Character Strengths and Virtues: A Handbook and Classification. Washington, DC 20002-4242: American Psychological Association, 2004.

19. M. Zuss, The Practice of Theoretical Curiosity. Dordrecht Heidelberg London New York: Springer, 2012.

20. G. Pluck, "Stimulating curiosity to enhance learning," no. December 2011, 2016.

21. M. Zion and I. Sadeh, "Curiosity and open inquiry learning," no. September 2007, 2014.

22. D. B. Thoman, C. Sansone, and M. Pasupathi, "Talking about interest exploring the role of social interaction for regulating motivation and the interest experience," 2007.

23. M. Mitchell, "Situational Interest: Its Multifaceted Structure in the Secondary School Mathematics Classroom," vol. 85, no. 3, pp. 424 436, 1993.

24. H. Kang, S. Lee, and C. K. Chui, "Flow-Based Image Abstraction," vol. 15, no. 1, pp. 62-76, 2009.

25. A. Egberink, A. H. Gijlers, and N. Saab, "The Effect of Task and Collaboration Support on Learning Processes and Learning Results in a CSCL Environment," in 11th International Conference on Computer Supported Collaborative Learning, CSCL 2015: Exploring the material conditions of learning: Opportunities and challenges for CSCL, 2015, pp. 719-720.

26. S. Dakhi, "Curious Students ' Learning and Simple Sentence Construction: Responses to Negative Teaching Attitude Performed by English Teacher in South Nias , North Sumatera , Indonesia," no. December 2016, 2019.

27. A. Y. Arditama, S. Wardani, E. Purwanti, and N. Hindarto, "Storybook Influence on Science Concept Comprehension Through Curiosity of Fifth Grade Elementary School Student," vol. 7, no. 1, pp. 1-9, 2018.

28. P. E. Paruntu, Y. L. Sukestiyarno, A. Priyono, and B. Prasetyo, "Analysis of Mathematical Communication Ability and Curiosity Through Project Based Learning Models With Scaffolding," vol. 7, no. 1, pp. 26-34, 2018.

29. M. S. dan Y. Kusmarni, "Menumbuhkan karakter rasa ingin tahu siswa dalam pembelajaran sejarah melalui media puzzle," pp. 230242, 2012.

30. M. A. Husni, "Keefektifan Pembelajaran Matematika dengan Problem Posing dan Problem Solving Ditinjau dari Prestasi dan Curiosity Effectiveness of Mathematics Instruction through the Problem Posing
Approach and Problem Solving Approach in Terms of the Achievement and Cu," vol. 9, pp. 11-21, 2014.

31. A. Muttaqiin and W. Sopandi, "Energy Transformation Topic Correlation between Pre-Classroom Reading Activity and Students Curiosity Energy Transformation Topic: Correlation between PreClassroom Reading Activity and Students ' Curiosity," J. Phys. Conf. Ser. 895 012021, 2017.

32. Zetriuslita, Wahyudin, and Jarnawi, "Mathematical Communication Ability And Curiosity Attitude Through Problem Based Learning And Cognitive Conflict Strategy Based On Academic Level: A Study In Number Theory," PEOPLE Int. J. Soc. Sci. ISSN 2454-5899, vol. 4 no. 2, pp. 726-742, 2018.

33. Zetriuslita, Wahyudin, and J. A. Dahlan, "Association Among Mathematical Critical Thinking Skill , Communication , And Curiosity Attitude As The Impact Of Problem-Based Learning And Cognitive Conflict Strategy ( PBLCCS ) In Number Theory Course,' J. Math. Educ., vol. 7, no. 1, pp. 15-24, 2018.

34. H. Hartini, "Budaya Belajar Suku Rejang," JOMSIGN J. Multicult Stud. Guid. Couns., vol. 2, no. 1, 2017.

35. R. Steven and S. Lukas, "[ Measuring Students ' Curiosity ]," A J. Lang. Lit. Cult. Educ. POLYGLOT Vol. 14 No. 2 Juli 2018, vol. 14, pp. 151-164, 2018

36. A. R. Fauzi, Zainuddin, and R. Al Atok, "Sosial Melalui Discovery," J. Teor. dan Praksis Pembelajaran IPS P-ISSN 2503-1201 | E-ISSN 2503-5307 (C) FIS, Univ. Negeri Malang 2017 http//journal2.um.ac.id/index.php/jtppips/ Achmad, 2017.

37. S. Reiss, "Six motivational reasons for low school achievement," Child Youth Care Forum, vol. 38, no. 4, pp. 219-225, 2009

38. M. Zuckerman, Behavioral expressions and biosocial bases of sensation seeking. Cambridge university press, 1994

39. J. T. Cacioppo, R. E. Petty, J. A. Feinstein, and W. B. G. Jarvis, "Dispositional Differences in Cognitive Motivation: The Life and Times of Individuals Varying in Need for Cognition," vol. 119, no. 2 pp. 197-253, 1996

40. M. Ainley, "Interest in learning and the disposition of curiosity in secondary students: Investigating process and context," in Interes and learning: Proceedings of the Seeon conference on interest and gender, 1998, pp. 257-266.

41. W. H. Maw and E. W. Maw, "An attempt to measure curiosity in elementary school children,” Am. Educ. Res. J., vol. 3, no. 2, pp. 147156, 1966.

42. A. Lizzio and K. Wilson, "Action Learning in Higher Education : an investigation of its potential to develop professional capability," vol 29, no. 4, 2004.

43. M. Eraut, Developing professional knowledge and competence Routledge, 2002

44. P. Hager, A. Gonczi, and J. Athanasou, "Assessment \& Evaluation in Higher Education General Issues about Assessment of Competence,' no. September 2013, pp. 37-41, 2006.

45. L. K. J. Baartman and E. de Bruijn, "Integrating knowledge, skills and attitudes : Conceptualising learning processes towards vocational competence," Educ. Res. Rev. J. homepage www.elsevier.com/locate/EDUREV Rev., no. December 2017, 2011.

46. J. R. Anderson and C. D. Schunn, "Implications of the ACT-R Learning Theory: No Magic Bullets Implications of the ACT-R Learning Theory : No Magic Bullets Department of Psychology," vol. $5,2000$.

47. D. R. Krathwohl, “A Revision of Bloom 's Taxonomy :," vol. 41, no. 4, pp. 212-219, 2002.

48. M. George E. Miller, "The Assessment of Clinical Skills/Competence/Performance.George E. Miller, M.D." Academic medicine, 1990

49. S. B. Thrun, "The role of exploration in learning control," 1992

\section{AUTHORS PROFILE}

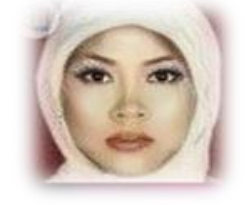

Hartini is a lecturer in the Islamic Education Counseling Guidance Study program at the Tarbiyah Faculty of the State Islamic Institute (IAIN). Currently pursuing her $\mathrm{PhD}$ at the Indonesian University of Education in Bandung, she is a candidate of educational doctor at the Indonesian University of Education in Bandung.

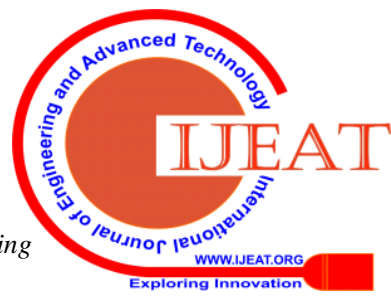




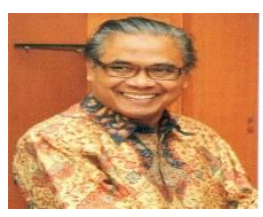

Sunaryo Kartadinata is a lecturer in the Counseling Guidance study program and professor at the Indonesian University of Education.

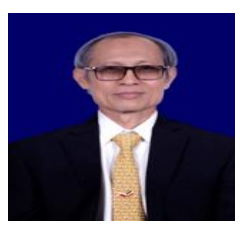

Syamsu Yusuf $\mathbf{L N}$ is a lecturer in the Counseling Guidance study program and professor at the Indonesian University of Education.



M. Solehuddin is a lecturer in the Counseling Guidance study program, currently serves as Vice Chancellor 1 at the Indonesian University of Education.

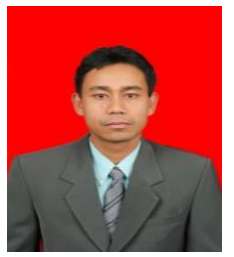

Edi Wahyudi $\mathbf{M}$ is a lecturer in the Madrasah Ibtidaiyah Teacher Education Study Program Faculty of Tarbiyah State Islamic Religion Institute (IAIN) $\mathrm{He}$ is a candidate of educational doctor at the Indonesian University of Education in Bandung 